\title{
Artikel \\ PEMANFAATAN DAUN KERSEN (Muntingia calabura L.) DALAM PENANGANAN DIABETES MELLITUS
} Penyegar

\author{
Dede Christian Kurnia ${ }^{1}$ \\ ${ }^{1}$ Fakultas Farmasi, Sekolah Tinggi Farmasi Indonesia, Bandung, Indonesia \\ Corresponding author's email : Dedeck58922@gmail.com
}

\begin{abstract}
ABSTRAK
Diabetes mellitus (DM) atau kencing manis, merupakan salah satu penyakit yang ditandai dengan tingginya nilai glukosa dalam darah. Diabetes mellitus disebabkan oleh gangguan metabolisme karbohidrat, lemak, dan protein, serta ketidakcukupan insulin yang dibutuhkan oleh tubuh.

Secara empiris, daun kersen dapat digunakan sebagai obat alternatif bagi penderita diabetes mellitus karena mempunyai substansi aktif berupa asam askorbat, serat, niasin, dan beta karoten. Daun kersen dapat digunakan untuk menangani diabetes mellitus tipe II karena mempunyai kandungan flavonoid dan antioksidan yang dapat menghambat kerusakan pancreas. Daun kersen yang sudah bersih biasanya direbus tanpa menggunakan bahan lain dengan menggunakan air $200 \mathrm{~mL}$ selama 15 menit hingga berwarna kuning. Daun kersen yang digunakan juga sebanyak 10 daun atau seberat 15 gram dalam sekali rebusan atau 1,5 gram dalam $100 \mathrm{~mL}$ untuk seduhan.

Rata-rata kadar gula darah sesudah dilakukan intervensi menurun sebesar 305,58 mg/dL menjadi $178,33 \mathrm{mg} / \mathrm{dL}$, di mana terdapat pengaruh yang signifikan pemberian rebusan daun kersen terhadap penurunan kadar glukosa darah. daun kersen lebih besar memberikan pengaruh terhadap penurunan kadar glukosa darah dengan jumlah rata-rata kadar glukosa darah sebesar 63,73 mg/dL sedangkan pada daun kelor hanya dapat menurunkan kadar glukosa darah dengan jumlah rata-rata sebesar $41,00 \mathrm{mg} / \mathrm{dL}$
\end{abstract}

Kata kunci: diabetes mellitus, daun kersen

\section{ABSTRACT}

Diabetes mellitus (DM) or known as diabetes, is one of the diseases caused by high blood sugar accompanied by impaired carbohydrate, fat, and protein metabolism due to $\mathrm{KH}$, protein, and fat metabolism causing high glucose values in the blood caused by the inadequacy of insulin needed by the body.

Empirically, cherry leaves can be used as an alternative medicine for diabetics because they have active substances in the form of ascorbic acid, fiber, niacin, and beta carotene. Cherry leaves that have been cleaned are usually boiled without using other ingredients using $200 \mathrm{~mL}$ of water for 15 minutes until they are yellow. Cherry leaves are also used as many as 10 leaves or weighing 15 grams in one stew.

The average blood sugar level after the intervention was decreased by $305.58 \mathrm{mg} / \mathrm{dL}$ to 178.33 $\mathrm{mg} / \mathrm{dL}$, where there was a significant effect in the administration of cherry leaves to a decrease in blood glucose levels. greater cherry leaves give an effect on decreasing blood glucose levels with an average amount of blood glucose levels of $63.73 \mathrm{mg} / \mathrm{dL}$ whereas on Moringa leaves can only reduce blood glucose levels by an average amount of $41.00 \mathrm{mg} / \mathrm{dL}$.

It can be concluded that cherry leaves can be used to treat type II diabetes mellitus because it contains flavonoids and antioxidants that can inhibit pancreatic damage.

Keywords : diabetes mellitus, cherry leaf

\section{PENDAHULUAN}


Diabetes mellitus (DM) atau kencing manis, merupakan salah satu penyakit yang ditandai dengan tingginya nilai glukosa dalam darah. Diabetes mellitus disebabkan oleh gangguan metabolisme karbohidrat, lemak, dan protein, serta ketidakcukupan insulin yang dibutuhkan oleh tubuh. Banyak faktor yang menyebabkan penyakit ini, diantaranya berupa pola makan, obesitas (kegemukan), faktor genetis, bahan-bahan kimia dan obat-obatan, penyakit dan infeksi pada pankreas, dan kehamilan (Stevani, 2016).

Diabetes Mellitus ini diderita oleh 415 juta orang dewasa di Asia Tenggara berdasarkan laporan statistik dari World Health Organization tahun 2015, dan diprediksi dapat mengalami kenaikan sebesar empat kali menjadi 629 juta penderita pada tahun 2045. Penyakit ini merupakan salah satu penyebab kematian nomor enam di Indonesia berdasarkan data dari WHO tahun 2019.

Diabetes mellitus disebabkan oleh sel $\beta$ pankreas yang rusak dimana sel ini merupakan sel yang yang menghasilkan insulin. DM sendiri terdapat jenis di mana DM tipe I disebabkan oleh sel $\beta$ pankreas tidak dapat memproduksi hormon insulin yang mengakibatkan kadar glukosa darah tidak berkurang, dan sedangkan DM tipe II disebabkan oleh resistensi insulin karena menurunnya sensitifitas reseptor insulin yang terdapat pada hati, jaringan adiposa, dan jaringan otot (Selvia dkk, 2015). Pengobatan diabetes melitus dapat dilakukan dengan pemberian obat secara oral, IV, dan subkutan berdasarkan Reni (2013). Pengobatan insulin efektif dalam menangani diabetes mellitus tipe I dan tipe I| dengan pankreas yang sudah rusak. Pencegahan diperlukan karena kerusakan pankreas yang semakin parah pada diabetes mellitus tipe II membutuhkan insulin dimana obat ini merupakan obat dengan harga yang cukup tinggi sehingga dapat menyebabkan beberapa penderita memilih tidak melakukan pengobatan, hal ini dapat berbahaya dalam jangka panjang sehingga dibutuhkan alternatif dimana diabetes mellitus tipe II dapat terobati walaupun pengobatan dalam jangka panjang, mudah dilakukan, dan harga yang terjangkau. Penanganan ini dapat dilakukan dengan menggunakan herbal yang berasal dari tumbuhan, karena alam Indonesia yang sangat beragam dengan berbagai manfaat dapat memberikan alternatif penanganan penyakit diabetes mellitus tipe II bagi masyarakat, salah satunya adalah daun kersen atau Muntingia calaburaL.

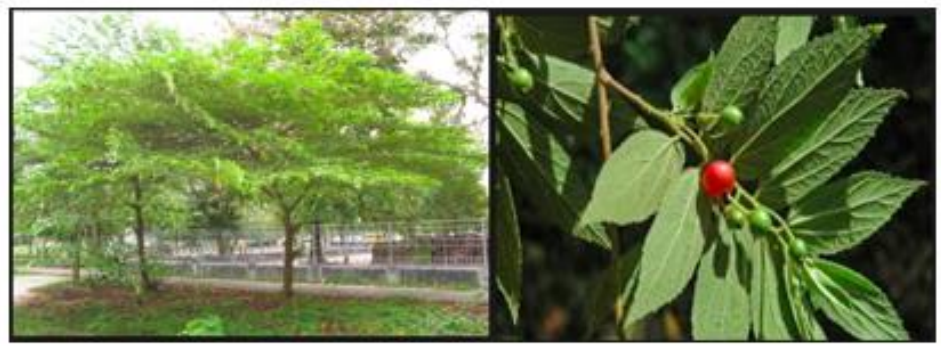

(a) (b)

Gambar 1. (a) Pohon kersen (b) Daun kersen

Daun kersen merupakan tanaman yang banyak dijumpai di pinggir jalan. Tanaman ini 
biasanya mempunyai ketinggian sebesar 3-12 meter, tersebar di seluruh Indonesia. Tumbuhan ini memiliki buah yang manis, berukuran kecil, dan berwarna merah jika buah sudah matang. Daun kersen sendiri mempunyai ukuran $14 \times 4 \mathrm{~cm}$, bagian bawah yang berbulu, dan daun bergerigi (Zahara, 2018)

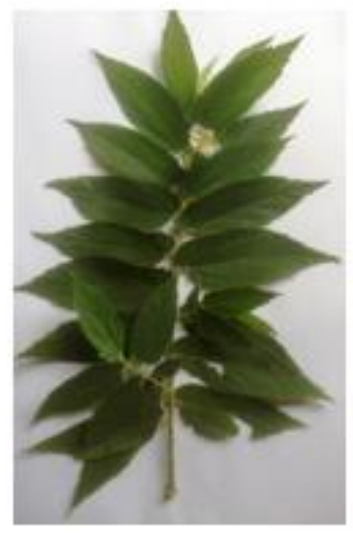

\section{Gambar 2. Susunan daun kersen}

Secara empiris, daun kersen dapat digunakan sebagai obat alternatif bagi penderita diabetes mellitus karena mempunyai substansi aktif berupa asam askorbat, serat, niasin, dan beta karoten. Daun kersen juga mempunyai senyawa kimia lainnya berupa protein, lemak, karbohidrat, abu, kalsium, fosfor, besi, tianin, riboflavin, niacin dan flavonoid (flavon, flavonon, flavan, dan biflavan). Daun ini juga mempunyai fungsi selain antidiabetes karena senyawa flavonoid dapat berfungsi sebagai antimikroba, antivirus, antioksidan, antihipertensi, merangsang pembentukan estrogen, dan mengobati gangguan fungsi pada hati (Zahara, 2018). Antioksidan dalam flavonoid dapat menghambat kerusakan yang terjadi pada sel beta pankreas secara terusmenerus, sehingga sel-sel beta pada pulau Langerhans di pankreas akan beregenerasi dan akan mensekresikan insulin kembali ke dalam darah sehingga cocok untuk penderita DM tipe II (Tuhfa, 2017).

\section{Penderita diabetes memerlukan}

pengobatan non farmakologis dan farmakologis dimana pengobatan non farmakologis dapat dengan melakukan olahraga yang cukup, mengonsumsi buah dan sayur atau terkontrol, tidak meminum minuman alkohol ataupun merokok. Dalam pengobatan farmakologis dapat melakukan pengobatan dengan pemerian insulin bagi penderita diabetes mellitus tipe II dengan pankreas yang hampir rusak tetapi dapat dicegah dengan alternatif menggunakan tanaman herbal daun kersen.

\section{ISI}

Daun kersen yang sudah bersih biasanya direbus tanpa menggunakan bahan lain dengan menggunakan air $200 \mathrm{~mL}$ selama 15 menit hingga berwarna kuning. Daun kersen yang digunakan juga sebanyak 10 daun atau seberat 15 gram dalam sekali rebusan. Rebusan ini biasanya dikonsumsi dua kali sehari, dan biasanya digunakan oleh usia lanjut agar dapat mengurangi diabetes (Norma dan Nur, 2019). 
Penelitian secara ilmiah telah banyak dilakukan untuk membuktikan bahwa daun kersen banyak digunakan sebagai obat alternatif penanganan diabetes, diantaranya penelitian dari Hendra Stevani, dkk tahun 2016 mengenai efektifitas rebusan daun kersen (Muntingia calabura L.) terhadap penurunan kadar glukosa darah pada mencit (Mus musculus L.). Daun kersen efektif dalam menurunkan kadar glukosa dengan konsentrasi sebesar $15 \%$ atau sama seperti dengan merebus 15 gram daun kersen dalam $100 \mathrm{~mL}$ air, penurunan kadar glukosa darah yang terjadi di dalam tubuh sebesar $98 \mathrm{mg} / \mathrm{dL}$, dimana penurunan ini sebanding dengan menggunakan obat glibenklamid. Dari penelitian ini juga didapatkan bahwa semakin tinggi konsentrasi

Tabel 1. Penurunan kadar glukosa pada mencit dengan glibenklamid dan rebusan daun kersen dengan konsentasi $5 \%, 10 \%$, dan 15\%b/v (Stevani, 2016).

\begin{tabular}{|c|c|c|c|c|c|c|c|c|c|}
\hline \multirow{3}{*}{ Perlakuan } & \multirow{3}{*}{ Replikasi } & \multicolumn{7}{|c|}{ Kadar Glukosa Darah Mencit (mg/dL) } & \multirow{3}{*}{ Penurunan } \\
\hline & & \multirow{2}{*}{ Puasa } & \multirow{2}{*}{$\begin{array}{l}\text { Setelah } \\
\text { Induksi }\end{array}$} & \multicolumn{5}{|c|}{ Setelah menit ke- } & \\
\hline & & & & 30 & 45 & 60 & 90 & 120 & \\
\hline \multirow{3}{*}{ Kontrol negatif } & I & 138 & 169 & 140 & 133 & 116 & 118 & 92 & 77 \\
\hline & II & 115 & 156 & 156 & 142 & 135 & 129 & 105 & 51 \\
\hline & III & 115 & 123 & 117 & 105 & 102 & 109 & 110 & 13 \\
\hline \multirow{3}{*}{ Glibenklamid } & $\mathrm{T}$ & 78 & 132 & 75 & 50 & 43 & 38 & 37 & 95 \\
\hline & II & 98 & 138 & 84 & 69 & 59 & 42 & 40 & 98 \\
\hline & III & 164 & 168 & 111 & 74 & 63 & 50 & 34 & 134 \\
\hline \multirow{3}{*}{$\begin{array}{c}\text { Rebusan kersen } \\
5 \% \mathrm{~b} / \mathrm{v}\end{array}$} & I & 84 & 114 & 90 & 105 & 109 & 79 & 81 & 33 \\
\hline & II & 87 & 145 & 105 & 78 & 88 & 98 & 90 & 55 \\
\hline & III & 126 & 130 & 119 & 113 & 84 & 80 & 76 & 54 \\
\hline \multirow{3}{*}{$\begin{array}{c}\text { Rebusan kersen } \\
10 \% \mathrm{~b} / \mathrm{v}\end{array}$} & I & 98 & 153 & 119 & 113 & 110 & 102 & 89 & 64 \\
\hline & II & 78 & 180 & 114 & 94 & 72 & 50 & 49 & 131 \\
\hline & III & 133 & 134 & 126 & 60 & 45 & 69 & 51 & 83 \\
\hline \multirow{3}{*}{$\begin{array}{c}\text { Rebusan kersen } \\
15 \% \mathrm{~b} / \mathrm{v}\end{array}$} & I & 87 & 132 & 119 & 69 & 67 & 50 & 34 & 98 \\
\hline & II & 143 & 118 & 92 & 62 & 59 & 60 & 49 & 69 \\
\hline & III & 108 & 161 & 78 & 78 & 49 & 43 & 33 & 128 \\
\hline
\end{tabular}

kersen terbukti dapat menurunkan kadar gula darah yang dilakukan pada hewan percobaan berupa mencit, dan didapatkan hasil bahwa daun (Stevani, rebusan daun kersen, maka semakin tinggi penurunan glukosa darah seperti pada tabel 1 . 2016)
Penelitian lainnya dilakukan oleh Selvia, Sri, Eva, J., dan Zohra (2015) dengan menggunakan mencit betina dan mencit jantan untuk mengetahui aktivitas anti diabetes perasan daun kersen tanpa direbus. Metode ini dilakukan dengan menimbang \pm 200 gram daun kersen yang sudah dicuci, daun kemudia ditumbuk hingga halus, lalu diperas dengan kain tipis. Hasil dari perasan daun kersen menunjukkan penurunan secara signifikan seperti penggunaan obat sintetik acarbose setelah pemberian perasan daun kersen dengan dosis efektif sebesar 0,2 ml/ 10grBB seperti pada tabel 2. Metode ini kurang baik jika dibandingkan dengan merebus daun kersen yang mempunyai efek penurunan lebih besar dalam tabel

1. 
Tabel 2. Penurunan kadar glukosa pada mencit jantan dan betina dengan glibenklamid dan rebusan daun kersen dengan dosis $0,1 \mathrm{ml}, 0,2 \mathrm{ml}$, dan $0,3 \mathrm{ml} / 10 \mathrm{grBB}$ (Selvia,

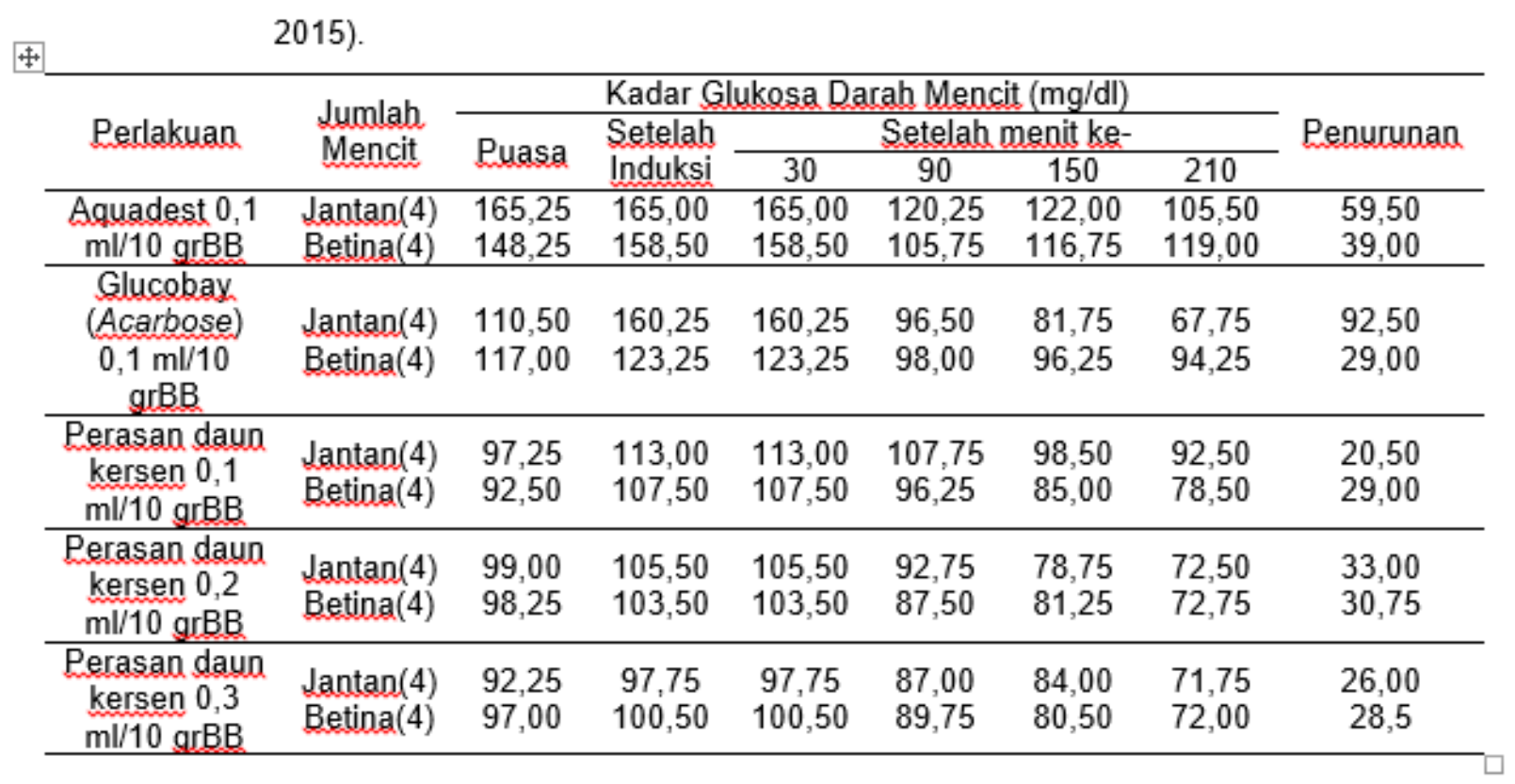

Penurunan kadar glukosa darah dalam penggunaan daun kersen disebabkan adanya senyawa flavonoid dalam daun kersen yang bersifat polar sehingga senyawa tersebut dapat larut dalam air. Zat ini yang mampu meregenerasi sel beta pankreas dan membantu merangsang sekresi insulin (Dheer dan Bhatnagar, 2010). Mekanisme lain dari flavonoid yang menunjukkan efek hipoglikemik yaitu mengurangi penyerapan glukosa dan mengatur aktivitas ekspresi enzim yang terlibat dalam metabolisme karbohidrat (Brahmachari, 2011). Senyawa dari golongan falvonoid berupa flavonols diduga memiliki aktifitas dalam menurunkan kadar glukosa dalam darah adalah kuersetin. Mekanisme kerja kuersetin bekerja dengan menjaga sel $\beta$ pankreas tetap bekerja secara normal (Norma dan Nur, 2018).

Penurunan kadar gula darah ini dibantu dengan menjaga konsumsi makanan atau minuman, dengan kadar glukosa rendah. Penggunaan dalam obat sintetik juga sebaiknya tidak digabungkan dengan penggunaan daun kersen karena akan mengalami efek perseptif berupa mual, atau bertambah hingga berkurangnya frekuensi buang air kecil dari penelitian yang dilakukan oleh Adhitia tahun 2012 dengan penelitian mengenai Efek Perseptif Penggunaan Antidiabetes Herbal Bersamaan dengan Penggunaan Obat Antidiabetes Oral pada Pasien Diabetes Melitus tipe 2 di Puskesmas Kotamadya Depok dengan hasil tidak adanya hubungannya antara frekuensi, lama penggunaan, dan peggunaan antidiabetes oral dengan munculnya efek-efek perseptif. Penggunaan obat sintetik dilakukan lebih baik jika sudah menghentikan sementara penggunaan daun kersen.

Efektifitas daun kersen diperkuat dengan pengujian secara klinis seperti penelitian yang 
dilakukan oleh Norma dan Nur tahun 2018 dengan menguji pengaruh rebusan daun kersen terhadap penurunan gula darah sewaktu pada klien diabetes mellitus tipe II di wilayah kerja puskesmas Klasaman Kota Sorong, dengan hasil adanya perbedaan signifikan antara kelompok yang tidak diberikan daun kersen dan kelompok yang menggunakan rebusan daun kersen dengan konsentrasi sebesar $15 \%$.

Tabel 3. Data kadar gula darah sewaktu antara kelompok kontrol dengan kelompok yang

\begin{tabular}{|c|c|c|c|c|c|c|}
\hline Kadar gula sewaktu & $\mathrm{n}$ & $\begin{array}{l}\text { Mean } \\
(\mathrm{mg} / \mathrm{dL})\end{array}$ & $\begin{array}{l}\text { Standar } \\
\text { deviasi }\end{array}$ & $\begin{array}{l}\text { Minimum- } \\
\text { maksimu } \\
\mathrm{m}(\mathrm{mg} / \mathrm{dL})\end{array}$ & $\begin{array}{l}\text { Statistic } \\
\text { Value }\end{array}$ & Kesimpulan \\
\hline $\begin{array}{l}\text { Kelompok interyensi } \\
\text { sebelum perlakuan }\end{array}$ & 30 & 237,13 & 28,60 & $200-300$ & & Normal \\
\hline $\begin{array}{l}\text { Kelompok setelah } \\
\text { Intervensi }\end{array}$ & 30 & 182,07 & 34,92 & $116-245$ & $\begin{array}{l}0,939 \\
0,371\end{array}$ & Normal \\
\hline $\begin{array}{l}\text { Kelompok kontrol } \\
\text { setelah intervensi }\end{array}$ & 30 & 210,93 & 40,82 & $132-296$ & $\begin{array}{l}0,979 \\
0,959\end{array}$ & Normal \\
\hline $\begin{array}{c}\text { Pre-test } \\
\text { Post-test }\end{array}$ & $\begin{array}{l}15 \\
15 \\
\end{array}$ & $\begin{array}{l}200 \\
116 \\
\end{array}$ & & $\begin{array}{l}200-300 \\
116-245 \\
\end{array}$ & & $p=0,046$ \\
\hline Eksperimen kentrol & $\begin{array}{l}15 \\
15\end{array}$ & $\begin{array}{l}182,07 \\
210,93\end{array}$ & $\begin{array}{l}34,925 \\
40,482\end{array}$ & & & $p=0,046$ \\
\hline
\end{tabular}

Rata-rata kadar gula darah sesudah dilakukan intervensi menurun sebesar 305,58 $\mathrm{mg} / \mathrm{dL}$ menjadi $178,33 \mathrm{mg} / \mathrm{dL}$, dimana terdapat pengaruh yang signifikan pemberian rebusan daun kersen terhadap penurunan kadar glukosa darah. Pada kelompok post-test intervensi memiliki nilai mean 182,07 mg/dL, sedangkan pada kelompok post-test konrol, memiliki nilai mean 210,83 mg/dL. Berdasarkan karakteristik menurut umur, responden terbanyak berada pada rentan umur 5665 tahun yakni 13 responden dengan persentasi $(43,3 \%)$. Dari data tersebut maka diabetes mellitus tipe 2 lebih banyak terjadi pada orang yang berumur di atas 40 tahun dari pada orang yang lebih muda (Norma dan Nur, 2018).

Penelitian selanjutnya secara klinis dilakukan oleh Tufha tahun 2017 di Desa Pangarangan, Kecamatan Kota Sumenep, Kabupaten Sumenep dimana daun kersen tetap menunjukkan penurunan diabetes yang signifikan dan lebih baik dibandingkan daun kelor dengan metode pembuatan seduhan daun kersen sebanyak 3 gram dalam $200 \mathrm{ml}$ air hangat dengan suhu $90^{\circ} \mathrm{C}$. Karakteristik responden tercantum dalam tabel 4. 
Tabel 4. Karakteristik responden di Puskesmas Pamolokan (Tuhfa, 2017).

\begin{tabular}{|c|c|c|c|c|c|c|c|}
\hline \multirow[t]{2}{*}{ No } & \multirow[t]{2}{*}{$\begin{array}{l}\text { Karakteristik } \\
\text { responden }\end{array}$} & \multicolumn{2}{|c|}{$\begin{array}{l}\text { Kelompok } \\
\text { Perlakuan } 1 \\
\text { (Daun kelor) }\end{array}$} & \multicolumn{2}{|c|}{$\begin{array}{c}\text { Kelompok } \\
\text { Perlakuan } 2 \\
\text { (Daun kersen) }\end{array}$} & \multicolumn{2}{|c|}{$\begin{array}{c}\text { Kelompok } \\
\text { kontrol } \\
\text { (Placebo) }\end{array}$} \\
\hline & & $\mathbf{N}$ & $\%$ & $\mathbf{N}$ & $\%$ & $\mathbf{N}$ & $\%$ \\
\hline \multirow[t]{4}{*}{1.} & Jenis Kelamin & & & & & & \\
\hline & Laki-laki & 4 & 36,4 & 4 & 36,4 & 4 & 36,4 \\
\hline & Perempuan & 7 & 63,6 & 7 & 63,6 & 7 & 63,6 \\
\hline & $\Sigma$ Responden & 11 & 100 & 11 & 100 & 11 & 100 \\
\hline \multirow[t]{5}{*}{2.} & Usia & & & & & & \\
\hline & $36-45$ th & 2 & 18,2 & 2 & 18,2 & 1 & 9,1 \\
\hline & $46-55$ th & 6 & 54,5 & 6 & 54,5 & 8 & 72,7 \\
\hline & $56-65$ th & 3 & 27,3 & 3 & 27,3 & 2 & 18,2 \\
\hline & Total & 11 & 100 & 11 & 100 & 11 & 100 \\
\hline \multirow[t]{4}{*}{3.} & Lama menderita DM & & & & & & \\
\hline & $1-2$ th & 4 & 36,4 & 4 & 36,4 & 4 & 36,4 \\
\hline & $3-4$ th & 7 & 63,6 & 7 & 63,6 & 7 & 63,6 \\
\hline & Total & 11 & 100 & 11 & 100 & 11 & 100 \\
\hline \multirow[t]{3}{*}{4.} & $\begin{array}{l}\text { OHO yang } \\
\text { dikonsumsi }\end{array}$ & & & & & & \\
\hline & Glibenclamide & 11 & 100 & 11 & 100 & 11 & 100 \\
\hline & Total & 11 & 100 & 11 & 100 & 11 & 100 \\
\hline \multirow[t]{4}{*}{5.} & $\begin{array}{l}\text { Kadar Glukosa darah } \\
\text { terakhir }\end{array}$ & & & & & & \\
\hline & $140-199 \mathrm{mg} / \mathrm{dL}$ & 2 & 18,2 & 2 & 18,2 & 0 & 0 \\
\hline & $>200 \mathrm{mg} / \mathrm{dL}$ & 9 & 81,8 & 9 & 81,8 & 11 & 100 \\
\hline & Total & 11 & 100 & 11 & 100 & 11 & 100 \\
\hline
\end{tabular}

Keterangan: $\quad \mathrm{N}$ : jumlah responden

Kelompok perlakuan 1 : Kelompok yang mendapatkan daun kelor (Moringa oleifera)

Kelompok perlakuan 2 : Kelompok yang mendapatkan daun kerson (Muntingia calabura

L.)

Penggunaan glibenclamide umum digunakan untuk penderita diabetes mellitus tipe II sehingga dalam penilitian Tufha digunakan sebagai pembanding. Dari karakteristik koresponden, dapat disimpulkan bahwa semakin tua maka akan semakin beresiko diabetes, dimana dalam penelitian ini sejalan dengan penelitian norma dan nur tahun 2018. Penggunaan daun kelor dapat digunakan sebagagai anti diabetes selain daun kersen karena keduanya mempunyai senyawa flavonoid berupa quercetin yang dapat meregulasi kadar glukosa darah dengan cara menghambat kerja enzim $\alpha$-glukosidase dan $\alpha$-amilase dalam usus berdasarkan tuhfa tahun 2017.

Nilai observasi kadar glukosa 2 jam postprandial pre-post untuk mengetahui berapa banyak kadar glukosa yang dicerna tubuh dan yang tidak dapat dicerna oleh tubuh selama 2 jam untuk mendapatkan hasil kerja sel $\beta$ pankreas dalam menghasilkan insulin pada kelompok kontrol, 
sedangkan untuk penggunaan daun kelor dan mengurangi kadar glukosa.

daun kersen untuk menilai efektifitas dalam

Tabel 5. Nilai observasi kadar glukosa darah 2 jam post-prandial pre-post dan selisih

\begin{tabular}{|c|c|c|c|c|c|c|c|c|c|}
\hline \multicolumn{10}{|c|}{ KGD 2 jam setelah makan/interyensi (mg/dL) } \\
\hline \multirow[t]{2}{*}{ No } & \multicolumn{3}{|c|}{$\begin{array}{c}\text { Kelompok Perlakuan } 1 \\
\text { (Daun kelor) }\end{array}$} & \multicolumn{3}{|c|}{$\begin{array}{c}\text { Kelompok Perlakuan } 2 \\
\text { (Daun kersen) }\end{array}$} & \multicolumn{3}{|c|}{$\begin{array}{c}\text { Kelompok kontrol } \\
\text { (Placebo) }\end{array}$} \\
\hline & Pre & Post & Selisih & Pre & Post & Selisih & Pre & Post & Selisib \\
\hline 1. & 138 & 106 & -32 & 135 & 69 & -66 & 108 & 128 & -20 \\
\hline 2. & 282 & 249 & -33 & 324 & 289 & -35 & 120 & 130 & -10 \\
\hline 3. & 285 & 250 & -35 & 289 & 223 & -66 & 129 & 135 & 6 \\
\hline 4. & 135 & 99 & -36 & 283 & 206 & -77 & 132 & 141 & 9 \\
\hline 5. & 326 & 224 & -102 & 275 & 205 & -70 & 347 & 330 & -17 \\
\hline 6. & 243 & 213 & -30 & 263 & 189 & -74 & 243 & 228 & -15 \\
\hline 7. & 256 & 224 & -32 & 258 & 192 & -66 & 230 & 211 & -19 \\
\hline 8. & 275 & 236 & -39 & 312 & 236 & -76 & 232 & 228 & 4 \\
\hline 9. & 247 & 213 & -34 & 249 & 203 & -46 & 240 & 220 & -20 \\
\hline 10. & 231 & 198 & -33 & 293 & 221 & -72 & 252 & 243 & -9 \\
\hline 11. & 321 & 276 & -45 & 286 & 211 & -75 & 223 & 212 & -11 \\
\hline Mean & 249 & 208 & - & 269,7 & 204 & - & 205,1 & 200,55 & - \\
\hline $\begin{array}{c}\text { Uji } \\
\text { deskriptif }\end{array}$ & & & -102 & & & -77 & & & -20 \\
\hline
\end{tabular}

Berdasarkan Kementrian Kesehatan (2013), jika kadar glukosa darah 2 jam post prandial 140-199 mg/dL maka termasuk kategori Toleransi Glukosa Terganggu dan $>200 \mathrm{mg} / \mathrm{dl}$ termasuk kategori Glukosa Terganggu. Toleransi glukosa terganggu dimana merupakan rentang antara kadar glukosa normal dengan batasan diabetes sehingga masih dapat ditoleransi dan belum masuk sebagai penderita diabetes.

daun kersen dalam penelitian ini juga mempunyai hasil efektifitas lebih besar dalam memberikan pengaruh terhadap penurunan kadar glukosa darah dengan jumlah rata-rata kadar glukosa darah sebesar $63,73 \mathrm{mg} / \mathrm{dL}$ sedangkan pada daun kelor hanya dapat menurunkan kadar glukosa darah dengan jumlah rata-rata sebesar 41,00 $\mathrm{mg} / \mathrm{dL}$ secara rata-rata (Tuhfa, 2017).

\section{PENUTUP}

24
Dapat disimpulkan bahwa daun kersen dapat digunakan untuk menangani diabetes mellitus tipe II karena mempunyai kandungan flavonoid dan antioksidan yang dapat menghambat kerusakan pankreas yang sudah diuji dengan menggunakan mencit dan pengamatan uji preklinis di mana kadar 15\% merupakan kadar optimum dalam rebusan untuk pengurangan kadar glukosa.

\section{DAFTAR PUSTAKA}

Adhitia. (2012, Juli). Efek Perseptif Penggunaan Antidiabetes Herbal Bersamaan dengan Penggunaan Obat Antidiabetes Oral pada Pasien Diabetes Melitus tipe 2 di Puskesmas. P. 43. May 24, 2020. http://lib.ui.ac.id/file?file=digital/20306390S42169-Adhitia.pdf

Brahmachari, G. (2011), 'Bio- Flavonoids With Promising Antidiabetic Potentials: A Critical Survey, Research Signpost'. P. 187-212.

B I M F I Volume 7 No.1 / Januari 2020 - Juni 2020 
Depkes RI. (2013). Hasil Riskesdas 2013Departeman Kesehatan Republik Indonesia. May 24, 2020. http://www.depkes.go.id/resource/download/gen eral/Hasil \%20Riskesdas\% 202013.pdf.

http://www.depkes.go.id/resource/download/genera I/Hasil\%20Riskesdas\% 202013.pdf.

Dheer R. \& Bhatnagar P. (2010). 'A study of the Antidiabetic Activity of Barleria prionitis Linn, Indian Journal of Pharmacology'. Vol 42 (2)p. 70-73.

Norma dan Nur. (2019, April). 'Pengaruh Rebusan Daun Kersen Terhadap Penurunan Gula Darah Sewaktu Pada klien diabetes mellitus tipe II di wilayah kerja puskesmas klasaman Kota Sorong Tahun 2018'. 3(2), p. 7-9. May 24, 2020. Doi : 2540-8283/2620-3294.

Reni. (2013). Diabetes Mellitus dan Terapi Insulin. 1(2), p. $7 . \quad$ May 24, 2020. http://pusdiklatmigas.esdm.go.id/file/p1_Terapi_Insulin_---_Reni_Febriana.pdf

Selvia, A., Sri, Eva, J., dan Zohra (2015). Uji Efektivitas Ekstrak Daun Kersen Muntingia calabura L. Terhadap Penurunan Kadar Glukosa Darah Pada Mencit Mus musculus L. p. 2. http://repository.unhas.ac.id/bitstream/handle/12 3456789/19202/jurnal\%20ayu\% 20fix.pdf?sequence=1

Stevani, H., Husnul, A.T., dan Nurul. (2017, April). Efektifitas Rebusan Daun Kersen (Muntingia calabura L.) Terhadap Penurunan Kadar Glukosa Darah Pada Mencit (Mus musculus L.), $7(1), \quad$ p. $\quad 20 . \quad$ May 24, 2020 .http://farmasi.poltekkes-mks.ac.id/images/April2017/hendra-stevani_husnul afifathamrin_nurulhidayah-basse .pdf

Tuhfa. (2017). Pengaruh Pemberian Seduhan Daun Kelor (Moringa Oleifera) Dan Seduhan Daun Kersen (Muntingia Calabura L) Terhadap Penurunan Kadar Glukosa Darah Pada Penderita Diabetes Mellitus Di Desa Pangarangan, Kecamatan Kota Sumenep, Kabupaten Sumenep. P. 54-56. May 24, 2020. http://repository. unair.ac.id/77576/2/full\%20text.pdf

WHO (2019) 'GLOBAL REPORT ON DIABETES'. p. 6-7.

Zahara. (2018, November). Kajian Morfologi dan Review Fitokimia Tumbuhan Kersen (Muntingia calabura L.). 5(2), p. 71. May 24, 2020. https://www.researchgate.net/publication/32917 5073_Kajian_Morfologi_dan_Review_Fitokimia _Tumbuhan_Kersen_Muntingia_calabura_L. 